UDC 811.111'367.622'37

$811.111^{\prime} 367.625$ '37

$81 ’ 364$

Maja Lubańska

University of Wroclaw, Poland

\title{
GRAMMATICALISATION AND GENERATIVE THEORY: THE CASE OF EPISTEMIC PROMISE
}

\begin{abstract}
The grammaticalisation theory and the generative theory have been commonly perceived as rather incompatible in their background assumptions (cf. Van Kemenade 1999, Fisher and Rosenbach 2000). Accordingly, the process of grammaticalisation has been often seen as inapplicable to the generative account of language. The aim of this paper is to show the reverse. Following the line of reasoning presented in Roberts and Roussou (1999, 2005), I will analyse the development of epistemic promise in English to show that Chomskyan theory can account not only for abrupt, categorial changes, but also for gradual, and ongoing ones.
\end{abstract}

Key words: grammaticalisation, generative theory, modality, epistemic modality, semantic factors, cognitive factors, pragmatic factors, minimalist grammar, morphosyntactic change, language acquisition,

\section{Introduction}

The grammaticalisation theory and the generative theory have been commonly perceived as rather incompatible in their background assumptions (cf. van Kemenade 1999, Fisher and Rosenbach 2000). Grammaticalisation theorists (Traugott and Heine 1991, Hopper and Traugott 1993, Heine and Kuteva 2005, Heine 2003, to name but a few) see semantic/ cognitive / pragmatic factors as the driving force of grammaticalisation. From the generative perspective, syntactic change is autonomous (Lightfoot 1979, 1991), which means independent of semantic or pragmatic factors, as it 
involves the interaction of morphology and syntax. However, the idea that grammaticalisation is not applicable to generative accounts of language has been recently challenged by Roberts and Roussou (1999, 2005), who successfully address the question of syntactic change in the context of Chomsky's $(1995,2000)$ minimalist framework. It is obvious that diachronic generative studies investigate the restructuring of the grammatical system that involves lexical to functional or functional to functional reanalysis. Since reanalysis, next to extension, semantic bleaching and phonetic reduction, is one of the main mechanisms of grammaticalisation, it seems that generative researchers explore only one aspect of grammaticalisation. This, however, should not be surprising at all. In grammaticalisation theory, reanalysis occurs after pragmatic and semantic factors have activated the process of grammaticalisation and have brought it to the morphosyntactic stage of change. And it is here that generative exploration starts.

It has been also pointed out that the evidence from grammaticalisation is not compatible with the generative view on language change. The aim of this paper is to show the reverse: that grammaticalisation is compatible with Chomskyan theory. Following Roberts and Roussou (1999, 2005), I will analyse the development of epistemic promise in English, a change which has not received much attention in the generative literature.

\section{Grammaticalisation and generative theory}

The central claims that Roberts and Roussou (1999:1020, 2005:2) make is that grammaticalisation is a case of parameter setting, which does not differ from any other change. As a result, it is not a distinct process, but an epiphenomenon. In the process of language acquisition, parameter values associated with functional categories are fixed on the basis of trigger experience. Roberts and Roussou (2005:12) put forward the weakly deterministic view of language acquisition. To account for language change, they do not maintain the view that the final state of language acquisition converges with the target/adult grammar learners are exposed to. Instead they refine the assumption by claiming that "language acquisition is deterministic to the extent that all parameters have to be set" (2005:12). This licenses language change: a parameter may receive a value inconsistent with the trigger experience as the convergence with adult grammar is not required. A change takes place when the trigger 
experience for a particular parameter setting becomes ambiguous. In this situation the learner relies on the learning device, which, as Roberts and Roussou (1999:1020, 2005:15) assume, prefers simpler representations as it is computationally conservative. Therefore if the parameter setting is not strongly triggered and thus the trigger experience is ambiguous, the learner will opt for the simpler representation, i.e. the one that does not involve a movement operation.

Another assumption underlying Roberts and Roussou's (1999, 2005) approach is that grammatical features can function as heads which project a phrasal category, following the $\mathrm{X}$ '-format in (1).

1)

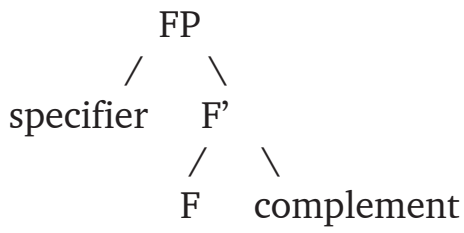

Roberts and Roussou strongly argue that functional (grammatical) elements are syntactic entities since they affect syntactic relations and are visible to syntactic operations, such as Merge or Agree. Furthermore, they argue for a greater availability of a number of functional heads, contra Chomsky (1995, 2000, 2001), who limits the number of available functional heads considerably. Yet another point where Roberts and Roussou (1999, 2005) are at variance with Chomsky is the interpretability of functional categories or features. They assume that functional features are LF-interpretable but they may or may not be PF-interpretable. If the latter is the case, the feature is either left unrealized at PF or it is realized by Move, i.e. by attracting another morpheme, or by Merge, i.e. by lexical insertion. As it is always the most economical option that is preferred, Merge is preferred over Move. Accordingly, parametric variation results from the way features are realized. This approach has major implications for grammaticalisation, which is now viewed as change from Move to Merge (Roberts and Roussou $1999,2005)^{1}$.

1 In later Minimalism (Chomsky 2004, 2005), Move is reformulated as Internal Merge, relevant for scope and discourse phenomena, and it is not considered less economical than regular Merge (now named External Merge), which is relevant to the argument structure. Van Gelderen (2008) argues for a reformulation of the account of grammaticalisation phenomena, which focuses on lexical instead of derivational characteristics. This reformulation results in the Feature Economy Principle, which requires that the semantic 
One of the linchpins of Roberts and Roussou's analysis is the idea that grammaticalisation involves reanalysis of functional categories, which results in the creation of new morphophonological realizations of functional features. In other words, a lexical item is reanalyzed as a functional item, and a functional item is realized as another functional item. This, however, is not a structural change since it is only the realization of features associated with functional heads that changes. The functional structure stays the same.

\section{Lexical verb > auxiliary analysis (Roberts and Roussou 1999, 2005)}

The development of English modal auxiliaries is a classic case of grammaticalisation whereby lexical verbs underwent a category change and became auxiliaries. Modern English auxiliaries are clearly distinguished from lexical verbs by their syntactic properties: they do not have non-finite forms, they do not allow iteration, they allow only bare infinitives as their complements, they do not allow do-support and always precede not, they can license VP fronting and can phonologically contract. To account for all these properties, Roberts and Roussou (1999: 1022-25, 2005: 36-48) claim that Modern English modal and auxiliary verbs merge directly in T, a position inaccessible to lexical verbs. Being members of $\mathrm{T}$, modals are affected by the properties of $\mathrm{T}$ such as finiteness or the lack of iteration. As Roberts and Roussou (1999:1023, 2005:37) explain, finiteness is a natural property of $\mathrm{T}$, and as there is only one $\mathrm{T}$, there cannot be more than one modal in a clause. Prior to the $16^{\text {th }}$ century, modals had none of the above-mentioned characteristics. Like lexical verbs, they were merged in $\mathrm{V}$ and then moved to T, which is illustrated by a biclausal structure in (2a). In the $16^{\text {th }}$ century, modals were reanalyzed from $\mathrm{V}$ to $\mathrm{T}$, which resulted in monoclausal structures, as in (2b), where there is no evidence for a biclausal structure (Roberts and Roussou 2005:40-41).

and interpretable features in the derivation are minimised. .In accordance with the principle, the grammaticalisation from a main verb to an auxiliary is seen as a reanalysis of the initially semantic features as interpretable ones, and then as uninterpretable ones. For details see van Gelderen (2008). 


\section{2) a. $\left[{ }_{\mathrm{TP}}\right.$ Sone $\left[{ }_{\mathrm{TP}}\right.$ hit mæi $\left[\mathrm{VP}_{\mathrm{VP}} \mathrm{t}_{\mathrm{mæi}}\left[_{\mathrm{TP}} \mathrm{T}\left[_{\mathrm{vp}}\right.\right.\right.$ ilimpen $\left.\left.\left.\left.]\right]\right]\right]\right]$ b. $\left[_{\mathrm{TP}}\right.$ Soon $\left[_{\mathrm{TP}}\right.$ it may $[\mathrm{VP}$ happen $\left.\left.]\right]\right]$}

As can be seen in (2b), V-to-T movement of the modal was lost, which gave rise to grammaticalisation: modals were reanalyzed from $\mathrm{V}$ to $\mathrm{T}$. This, in consequence, resulted in the reanalysis of the biclausal structure as the monoclausal one. This reanalysis was caused by the loss of infinitival morphology -en. Previously $\mathrm{T}$ attracted $\mathrm{V}$ with relevant morphology. When the infinitive ending was lost, for NP to VP constructions appeared, which is generally taken to provide evidence for $\mathrm{T}^{*}$ merge, with to in $\mathrm{T}$. As Roberts and Roussou (1999:1022-25, 2005:41-42) explain, the presence of infinitival ending was strong evidence for the lower T. Since modals were tensed, they were the higher $\mathrm{T}$, and the infinitival ending was the lower $\mathrm{T}$. When the infinitival ending was lost, (2a) was reanalyzed as (2b) due to the fact that there was no other evidence for the lower $\mathrm{T}$, and consequently for two Ts. As a result, modals became monoclausal, and there was no longer a need for V-to-T movement. Having been grammaticalised as elements of $\mathrm{T}$, modals acquired the properties that distinguish them now from lexical verbs: they lost their argument structure, and consequently the ability to be complemented by an element other than a bare infinitive; they lost their non-finite forms; and they took on complementary distribution with supporting do (Roberts and Roussou 2005:42). Following Roberts (1985, 1999), Roberts and Roussou (1999:1025, 2005:43) point out that later in the $16^{\text {th }}$ century (or even later) V-to-T movement of main verbs was lost. As a result, only members of $\mathrm{T}$ (auxiliaries) could precede the clausal not and invert. At that point English modals became a syntactically restricted class of verbs.

To sum up, Roberts and Roussou $(1999,2005)$ see the evolution of the English modals as consisting of three independent changes: first, some modals were reanalyzed; second, all modals were reanalyzed as a result of the loss of the infinitival morphology; third, the V-to-T movement was lost. The loss of infinitival morphology and the loss of V-to-T movement resulted in the reanalysis of the biclausal modal structures to the monoclausal ones. All these together gave rise to the development of modal verbs as a distinct class in English. 


\section{The development of epistemic promise}

Traugott (1993, 1997) and Verhagen (1995, 2000) distinguish the performative and the epistemic meanings of promise, such as in (3a) and (3b) respectively (Verhagen 2000).

3) a. I promise to come to the party.

b. Tomorrow promises to be a fine day.

The promise in (3a) describes an occurrence of the speech act of promising, giving information about the subject which is independent of the rest of the sentence. In (3b), promise expresses an evaluation on the part of the speaker of the validity of the proposition. As noted by Traugott (1993, 1997), promise was borrowed into Middle English in the early $15^{\text {th }}$ century from French as an illocutionary and performative verb. It is future-oriented and serves as a declaration that one will or will not do something. As illustrated in (4a-c), promise has a full syntactic potential as it occurs with (a) finite, (b) non-finite, and (c) nominal complements (Traugott 1993, 1997). In all these cases the subject is animate as it must be an entity able to fulfil the promise.

4) a. and I beseech your Grace to promise to his Highnes for mee that I will not onely fill my pockets with papers... (1570-1640, Official Letters 2, p. 156-7)

b. And promysed Kyng Herowde without delay / To come ageyn by hym - this is no nay (c. 1500 Digby Plays 97)

c. and there asked hym a gyffte that he promised her whan she gaff hym the swerde (bef. 1470 Works of Thomas Malory 48)

In (4), as well as in (5), promise is a control verb coindexing the subjects of the matrix and the subordinate clause. Examples in (5), however, illustrate the change that took place in the $16^{\text {th }}$ century: promise developed an epistemic meaning 'to give preindication of $X$ ', and can now be followed only by a nominal complement (Traugott 1993, 1997). The subject, in the majority of cases, is inanimate. 
5) a. the Title of this Paper promising some Experiments about the Production of Electricity, I must not omit to recite... (16751676, Boyle, Electricity and Magnetism 20-21)

b. As the morning promised a fair day we set out, but the storm coming up again we were obliged to come to. (1784 Muhl)

This is a transitional stage from a control verb to a raising verb, where promise is gradually losing the thematic control as it allows non-human subjects and epistemic meanings of the kind: "there is something about the subject that leads to an expectation of the proposition coming into being" (Traugott 1997:188). Next, in the $18^{\text {th }}$ century promise developed raising uses with non-finite complements. This is illustrated in (6), where the meaning is clearly non-intentional and epistemic: the speaker indicates that there is evidence for a particular expectation, and evaluates it in a positive way. The subject is not the source of the promise and it does not control the event expressed by the predicate.

6) a. The Capitol promised to be a large and handsome building, judging from the part about two thirds above ground. (1795 Twin)

b. The Pet Shop Boys' tour promises to be orchestrated with an imagination and attention to detail that makes most of their competitors look positively pedestrian. (1992 Guardian)

c. He promised to be stout when he grew up. (1722 Defoe)

d. As poor Jane promises to be pretty, she may be married off my hands. (1832) 
The general development of epistemic promise is summarized in Table $1^{2},{ }^{3}$.

\begin{tabular}{|l|l|l|l|}
\hline Stage & Verbal meaning & Complementation type & Subject \\
\hline $15^{\text {th }}$ c. & $\begin{array}{l}\text { a commitment to do } \\
\text { sthg } \\
\text { (non-epistemic use) }\end{array}$ & $\begin{array}{l}\text { finite complements } \\
\text { non-finite complements } \\
\text { nominal complements }\end{array}$ & $\begin{array}{l}\text { animate, it controls } \\
\text { the predicate, it is the } \\
\text { source of the promise }\end{array}$ \\
\hline $16^{\text {th }}$ c. & $\begin{array}{l}\text { to pre-indicate sthg } \\
\text { (epistemic use) }\end{array}$ & nominal complements & $\begin{array}{l}\text { animate/inanimate, it } \\
\text { controls the predicate } \\
\text { it is the source of the } \\
\text { promise }\end{array}$ \\
\hline $18^{\text {th }}$ c & $\begin{array}{l}\text { to pre-indicate sthg } \\
\text { (epistemic use) }\end{array}$ & non-finite complements & $\begin{array}{l}\text { animate/inanimate, it } \\
\text { does not control the } \\
\text { predicate, it is not the } \\
\text { source of the promise }\end{array}$ \\
\hline
\end{tabular}

Table 1. The development of epistemic promise in English (based on Traugott 1997)

As Traugott $(1993,1997)$ claims, the changes that promise has undergone, which are characteristic of raising verbs in general, are evidence for incipient grammaticalisation from the main verb to a semi-auxiliary. This results from the loss of some of its categorial properties as the main verb.

2 The sources describing the development of promise (Traugott 1993, 1997; Heine and Kuteva 2006) show it as one proceeding in stages. They differ in the number of stages listed and in the properties of the subject at a particular stage. For instance, Traugott (1993) distinguishes five stages, Traugott (1997) lists three stages and Heine and Kuteva (2006) describe four stages. Heine and Kuteva's and Traugott's stages differ as far the [ \pm animate]-property of the subject is concerned. For Heine and Kuteva stage-two promise occurs with inanimate subjects, while Traugott claims that it can be either animate or inanimate. In Heine and Kuteva's (2006) analysis, the difference between stage three and stage four lies in the property of the subject: stage-three promise occurs with nonfinite complements and inanimate subjects (the subject does not control the predicate as it is not the source of the promise); stage four is an extension of stage-three promise to contexts involving human subjects. Since a general presentation of the development of epistemic promise is sufficient for the purposes of this paper, I will use the three-stage schema, as presented in Traugott (1997).

3 Note that the rise of a new stage does not result in the termination of the previous one, on the contrary, they continue to coexist.

4 Although inanimate subjects are frequently observed at this stage (and inanimate subjects generally do not control their predicates), there is a strong tendency still present to attribute an agentive function to the subject. 
For example, epistemic promise cannot assign a theta-role to its subject and can be used in idiom chunks. Furthermore, epistemic (raising) promise cannot occur with the progressive aspect (Traugott 1993:355, 1997:194), which is illustrated in (7).

7) a. Marianne is promising to be a good president.

(locutionary and control only)

b. Marianne promises to be a good president.

(locutionary or epistemic, control or raising)

As noted by Traugott, further evidence for promise losing its categorial properties comes from its co-occurrence patterns with modal verbs. Full lexical epistemic verbs, such as insist or suggest, and raising verbs, such as seem and appear, occur both with deontic and with epistemic modals, whereas epistemic promise occurs with epistemic modals only (1993:356, 1997:196-7). This is shown in (8) and (9) respectively.

8) a. The Dean may suggest that Daniel cheats

i) but that should be her decision. (deontic)

ii) and if so I will back her up. (epistemic)

b. The confrontation may/must appear to escalate into war

i) so that we can persuade congress to declare war. (deontic)

ii) but it's actually not doing so. (epistemic)

c. She might/must appear to be a good attorney

i) so that we can expose them. (a Portia-like situation; deontic)

ii) but I don't believe she is one. (epistemic)

d. She may/must promise to be a good attorney

i) but that should be her decision. (deontic)

ii) but I don't believe her. (epistemic)

9) a. The conflict may promise to escalate into war

i) *so that we can distract the public's attention away from increased taxes. (deontic)

ii) but we have to make sure that it does not do so. (epistemic)

Traugott (1997:197) points out that the restriction on co-occurrence with modal auxiliaries shown by epistemic promise conforms to the constraint that a central modal preceding a quasi-modal must be epistemic. 
As has been pointed out in a number of sources (Traugott 1993, 1997; Heine and Kuteva 2006, among others), the changes that promise has undergone are the outcome of a grammaticalisation process leading from the full lexical verb to the semi-auxiliary. Promise has lost its lexical semantics and is now used to express the epistemic modality of probability. What is more, promise has been decategorialised towards an auxiliary: its syntactic potential is considerably reduced and some of its categorial properties as a lexical verb are lost. The existing evidence demonstrates beyond doubt that promise has changed its categorial status.

Despite the significant changes in its syntactic behaviour, promise ${ }^{5}$ has retained most of its lexical verb characteristics. Table 2, based on the criteria for auxiliary verbs in Quirk et al. (1985:137), shows the auxiliary and the main verb properties of promise.

\begin{tabular}{|c|c|c|c|}
\hline $\begin{array}{l}\text { Auxiliary } \\
\text { criteria }\end{array}$ & Auxiliary & Main verb & $\begin{array}{l}\text { Epistemic } \\
\text { promise }\end{array}$ \\
\hline $\begin{array}{l}\text { Operator in } \\
\text { negation }\end{array}$ & $\begin{array}{l}\text { YES } \\
\text { He cannot go. }\end{array}$ & $\begin{array}{l}\text { NO } \\
{ }^{*} \text { He hopes not to go }{ }^{6} \text {. }\end{array}$ & NO \\
\hline $\begin{array}{l}\text { Negative } \\
\text { contraction }\end{array}$ & \begin{tabular}{|l} 
YES \\
can't
\end{tabular} & $\begin{array}{l}\text { NO } \\
\text { *hopen't }\end{array}$ & NO \\
\hline $\begin{array}{l}\text { Operator in } \\
\text { inversion }\end{array}$ & $\begin{array}{l}\text { YES } \\
\text { Can we go? }\end{array}$ & $\begin{array}{l}\text { NO } \\
\text { *Hope we to go? }\end{array}$ & $\mathrm{NO}$ \\
\hline $\begin{array}{l}\text { Emphatic positive } \\
\text { with do }\end{array}$ & $\begin{array}{l}\text { NO } \\
* \text { *Yes, I DO can } \\
\text { come. }\end{array}$ & $\begin{array}{l}\text { YES } \\
\text { Yes, I DO hope to come. }\end{array}$ & YES \\
\hline $\begin{array}{l}\text { Operator in } \\
\text { reduced clause }\end{array}$ & $\begin{array}{l}\text { YES } \\
\text { I can come if you } \\
\text { can. }\end{array}$ & $\begin{array}{l}\text { NO } \\
\text { I hope to come if you } \\
\text { hope. }\end{array}$ & NO \\
\hline $\begin{array}{l}\text { Position of } \\
\text { adverb }\end{array}$ & $\begin{array}{l}\text { AUX + Adv } \\
\text { We can always go } \\
\text { early. }\end{array}$ & $\begin{array}{l}\text { Adv + verb } \\
\text { We always hope to go } \\
\text { early. }\end{array}$ & $\begin{array}{l}\text { Adv + verb } \\
\text { ?verb }+\mathrm{Adv}^{7}\end{array}$ \\
\hline
\end{tabular}

${ }^{5}$ For the sake of simplicity I will refer to epistemic promise as promise, unless otherwise stated.

6 This sentence is correct in the sense 'He hopes that he will not go' when it is 'to go' that is negated.

7 Traugott (1997:195-6) notes that as far as the position of adverbs is concerned, for some speakers promise and threaten behave like ought to and can:

i. The conflict certainly threatens to erupt into war.

ii. The conflict threatens certainly to erupt into war. 


\begin{tabular}{|c|c|c|c|}
\hline $\begin{array}{l}\text { Position of } \\
\text { quantifier }\end{array}$ & $\begin{array}{l}\text { AUX + quantifier } \\
\text { They can all come. } \\
\text { ?Quantifier + AUX } \\
\text { ?They all can come. }\end{array}$ & $\begin{array}{l}\text { Quantifier + verb } \\
\text { They all hope to come. } \\
\text { ? verb + quantifier } \\
\text { ?They hope all to come. }\end{array}$ & $\mathrm{Q}+$ verb \\
\hline $\begin{array}{l}\text { Independence of } \\
\text { subject }\end{array}$ & $\begin{array}{l}\text { Ann can do it. } \\
\text { It can be done by } \\
\text { Ann. }\end{array}$ & $\begin{array}{l}\text { He hopes to do it. } \\
\text { *It hopes to be done by } \\
\text { him. }\end{array}$ & $*$ \\
\hline \multicolumn{4}{|l|}{$\begin{array}{l}\text { Modal auxiliary } \\
\text { criteria }\end{array}$} \\
\hline Bare infinitive & $\begin{array}{l}\text { YES } \\
\text { I can go. }\end{array}$ & $\begin{array}{l}\text { NO } \\
\text { *I hope go. }\end{array}$ & $\mathrm{NO}$ \\
\hline $\begin{array}{l}\text { Absence of non- } \\
\text { finite forms }\end{array}$ & $\begin{array}{l}\text { YES } \\
* \text { to can/*canning/ } \\
* \text { canned }\end{array}$ & $\begin{array}{l}\text { NO } \\
\text { to hope/hoping/hoped }\end{array}$ & $\begin{array}{l}\text { YES } \\
\text { (no epistemic } \\
\text { interpretation } \\
\text { with non-finite } \\
\text { forms) }\end{array}$ \\
\hline $\begin{array}{l}\text { Absence of -s } \\
\text { form }\end{array}$ & $\begin{array}{l}\text { YES } \\
* \text { She cans come. }\end{array}$ & $\begin{array}{l}\text { NO } \\
\text { She hopes to come. }\end{array}$ & NO \\
\hline $\begin{array}{l}\text { Abnormal time } \\
\text { reference }\end{array}$ & $\begin{array}{l}\text { YES } \\
\text { You could leave this } \\
\text { evening. [not past } \\
\text { time] }\end{array}$ & $\begin{array}{l}\text { NO } \\
\text { You hoped to leave this } \\
\text { evening. [past time] }\end{array}$ & NO \\
\hline
\end{tabular}

Table 2. Epistemic promise vs. auxiliaries and main verbs

\begin{tabular}{|l|l|l|l|}
\hline Auxiliary criteria & $\begin{array}{l}\text { Semi-auxiliary: } \\
\text { have } \text { to }^{8}\end{array}$ & $\begin{array}{l}\text { Semi- } \\
\text { auxiliary: } \\
\text { be going to }\end{array}$ & Epistemic promise \\
\hline Operator in negation & NO & YES & NO \\
\hline Negative contraction & $\mathrm{NO}^{9}$ & YES & NO \\
\hline
\end{tabular}

Traugott (1997), however, does not illustrate the order promise + adverb with an example.

8 The aim of this comparison is to show that semi-auxiliaries are not a homogenous class. I have chosen have to and be going to since they are both semi-auxiliaries, but they do not have the same characteristics. Aiming to show the contrast, I ignored the form have got to, which has more auxiliary characteristics than the semantically parallel have to.

9 According to Swan (2002:244), have to can be used like a main verb with operator in questions and negatives, or like an auxiliary verb. Not negation, however, has always been rare for have to. In his corpus-based study of modal verbs, Krug (2000:103-106) points out the virtual absence of not negation of have to in present-day written and spoken English. 


\begin{tabular}{|c|c|c|c|}
\hline Operator in inversion & NO & YES & NO \\
\hline $\begin{array}{l}\text { Emphatic positive with } \\
\text { do }\end{array}$ & YES & NO & YES \\
\hline $\begin{array}{l}\text { Operator in reduced } \\
\text { clause }\end{array}$ & YES & YES & $\mathrm{NO}$ \\
\hline Position of adverb & $\begin{array}{l}\text { Adv + have to } \\
\text { have to + Adv }\end{array}$ & $\begin{array}{l}\text { Adv + be } \\
\text { be + Adv }\end{array}$ & $\begin{array}{l}\text { Adv }+ \text { promise } \\
\text { ?promise + Adv }\end{array}$ \\
\hline Position of quantifier & $\begin{array}{l}\text { quantifier }+ \\
\text { have to }\end{array}$ & $\begin{array}{l}\text { quantifier }+ \text { be } \\
\text { be }+ \text { quantifier }\end{array}$ & $\begin{array}{l}\text { Quantifier }+ \\
\text { promise }\end{array}$ \\
\hline $\begin{array}{l}\text { Independence of } \\
\text { subject }\end{array}$ & $\begin{array}{l}\text { It has to be } \\
\text { done by John. }\end{array}$ & $\begin{array}{l}\text { It's going to be } \\
\text { done by John. }\end{array}$ & $*$ \\
\hline \multicolumn{4}{|l|}{$\begin{array}{l}\text { Modal auxiliary } \\
\text { criteria }\end{array}$} \\
\hline Bare infinitive & $\mathrm{NO}$ & $\mathrm{NO}$ & $\mathrm{NO}$ \\
\hline $\begin{array}{l}\text { Absence of non-finite } \\
\text { forms }\end{array}$ & $\mathrm{NO}$ & $\mathrm{NO}$ & YES \\
\hline Absence of $-\mathrm{s}$ form & NO & NO & NO \\
\hline $\begin{array}{l}\text { Abnormal time } \\
\text { reference }\end{array}$ & $\mathrm{NO}$ & NO & $\mathrm{NO}$ \\
\hline
\end{tabular}

Table 3. Epistemic promise vs. semi-auxiliaries

As can be seen from Table 2, promise has retained most of its main verb characteristics. In contrast, the data presented in the previous section show that it has undergone incipient grammaticalisation on the way to become a semi-auxiliary. Epistemic promise occurs only with non-finite complements, it cannot assign a subject theta-role, it cannot occur with the progressive aspect and deontic modal verbs. The change in its categorial status is noted when promise is compared to semi-auxiliaries. As the data in Table 3 show, promise and have to exhibit quite a similar syntactic behaviour: promise resembles have to in 8 out of 12 criteria. Both have to and promise, however,

The latest attestations are from 1955 and 1961. In the spoken British National Corpus, there are 12 attestations of not negation of have to, and 954 attestations of do negation. Krug (2004:104) also points out that not negation is found only in the language of older speakers. A similar observation is made by Collins (2009:66), who shows that have to takes only external negation. As far as question formation is concerned, the analysis presented by Krug (2000) confirms that have to occurs predominantly with do support.

The low productivity of not negation of have to is used by Krug (2000) to show the increased bonding between the two constituents: have and to. This bonding results in the emergence of a new form: hafta, where the morpheme to cliticises on the verbal host. This, of course, is not the case with promise. 
meet fewer auxiliary criteria than be going to. Be going to obviously satisfies more of them as its first word is the primary verb be, which functions as the operator. As noted by Quirk et al. (1985:143), under a more strict interpretation of the operator criteria, be going to would have to add not to the second or third word to form negation (*is goingn't to or *is going ton't). Be going to, and other semi-auxiliaries introduced by be, such as be able to, be about to, or be bound to, require a special interpretation of the operator criteria to be classified as auxiliary-like. Considering this, be going to, have to and promise become less distant on the semi-auxiliariness scale. The data in Table 3 clearly show that the boundaries of semi-auxiliaries as a category are not clear, with the members not meeting all the criteria. Consequently, it seems plausible to conclude that these boundaries may be extended to include promise.

\section{Epistemic promise in the generative paradigm ${ }^{10}$}

Despite the apparent changes, promise has not acquired all properties of semi-auxiliaries. It is thus interesting if the generative paradigm, which seeks to identify discrete parametric changes, can account for epistemic (functional) promise. The generative paradigm (Roberts and Roussou 1999, 2005) sees grammaticalisation as the loss of movement: in the case of verbs, a grammaticalised element (modal verb) is merged directly into the functional system (T), while a lexical verb is a member of V. Roberts and Roussou (2005:47) adopt the structure in (10) and explain that lexical verbs are merged in $\mathrm{V}$ and then move to $\mathrm{v}$ and $\mathrm{T}$.

$$
\text { 10) }\left[_{\mathrm{TP}} \mathrm{T}[\mathrm{vP} V[\mathrm{VP} V]]\right.
$$

In the VP shell in (10), the lower VP determines the thematic role of objects, whereas the higher vP determines that of subjects. Under this approach, epistemic modals are merged in $\mathrm{T}$, which makes the lower positions inaccessible to them and results in their lack of argument structure and nonfinite forms. Dynamic modals, which are subject oriented and determine their argument structure as far as the subject is concerned, are merged in $\mathrm{v}$ and then moved to $\mathrm{T}$. Being merged in $\mathrm{v}$, the modal verb may determine

\footnotetext{
${ }^{10}$ I thank professor Joanna Błaszczak (Wrocław Uniwersity) for her comments on an earlier draft of this section.
} 
the realization of the subject argument and show tense distinctions, yet it is not considered a lexical verb, which is merged in $\mathrm{V}$ (Roberts and Roussou 2005).

The fundamental question is where exactly epistemic promise merges into the structure. Lexical verbs do not raise into the functional system in modern English, but they are merged in the verbal functional system. They have their argument structure and impose restrictions on the interpretation of the subject, i.e. it must be [+animate]. Modal verbs, on the other hand, are elements of $\mathrm{T}$, a functional projection which does not assign theta roles. As a result, they do not have their argument structure, which in turn leads to the restriction on their structural complement: it can be a VP only. As members of T, modals precede the clausal negation, move to $\mathrm{C}$ in inversion contexts and do not have non-finite forms. As can be seen from Table 2, epistemic promise still has a number of main verb properties. Nevertheless, it does not have a subject theta role to assign and does not restrict the subject (it can be either animate or inanimate), but it does impose restrictions on its complement, which can be only a non-finite clause. As its argument structure is clearly defective, which is characteristic of functional elements, promise may be merged in a functional position. It cannot be merged in $\mathrm{T}$ as, unlike modals, it never precedes the clausal negation and shows tense distinctions. However, it can be assumed that promise, similarly to dynamic modals, which exhibit the properties of both lexical and modal verbs (Roberts and Roussou 2005:47), is merged in $\mathrm{v}^{11}$. This would legitimize its behaviour: a limited ability to participate in argument structure, and the manifestation of tense distinctions. This seems compatible with what Roberts and Roussou propose: "if we take the basic difference between lexical verbs and verbal functional heads to be the possession of argument structure, then we can think that merger directly into the functional system correlates with the absence of argument structure" (2005:44). This analysis accounts for the differences between epistemic/functional promise (merged in v), lexical verbs (merged in V) and modal verbs (merged in $\mathrm{T}$ ), as it does not regard promise as either a lexical or a modal verb.

${ }^{11}$ This does not mean that functional promise is exactly like dynamic modals. Dynamic modals are merged in $\mathrm{v}$, as in this position they can take an external argument, and are moved further to T (Roberts and Roussou 2005). Functional promise, unlike dynamic modals, does not impose a thematic restriction on its subject, and it is not moved to T. It is assumed here that the only property that they both share is the functional position in which they are merged (v). 
Maja Lubańska, Grammaticalisation and generative theory: ...

There are two more properties that need to be accounted for: promise's inability to impose a thematic restriction such as animacy or agentivity on the subject, and its epistemic interpretation. These properties are illustrated by the sentences in (11), in which promise occurs with both inanimate and animate subjects, and it has an epistemic meaning related to knowledge and belief (it indicates an evaluation by the producer of the utterance).

11)a. The notion of implicature promises to bridge the gap, by giving some account of how at least large portions of the italicized material in (3) are effectively conveyed. (S.C. Levinson, Pragmatics, 1987; BNC: J2K 903)

b. Preparations are now well advanced for this year ride, which promises to be bigger and better. (The Alton Herald, 1992; BNC: C88 1449)

c. Saturday promises to be a great day for the public and will give children a chance to see the cars which were made famous for them through the Back to the Future film. (Belfast Telegraph, 1992; BNC: K31 258)

d. Stefan Schumacher Gerolsteiner ... is one of cycling's top upand-coming stars. After bursting onto the scene and into the pink leader's jersey for a couple of days of the 2006 Tour of Italy, Schumacher powered his way to victory in this year's Amstel gold race. The versatile 25-year-old German promises to be a force in the opening week of racing. (Bicycling 48(7), 2007; COCA)

In sentences such as those in (11), promise is a raising verb ${ }^{12}$. Raising verbs fail to impose selectional requirements on the subject of their clause, as originally observed by Burzio (1986). They belong to the class of unaccusatives, which means that they take one internal clausal argument and do not assign an external theta role to the subject position. The interpretation arising in the raising construction is an epistemic one. Therefore it may be assumed that functional promise is inherently

\footnotetext{
${ }^{12}$ Wurmbrand (2001:205-215) claims that raising verbs in German, including versprechen 'to promise', are epistemic modals occurring in the highest functional head of the modal domain. English raising verbs, however, differ from German ones in syntactic behaviour, thus the same type of analysis cannot be applied to English. For a detailed discussion of German raising constructions see Wurmbrand (2001).
} 
epistemic: it acquires epistemic reading as a raising construction, similarly to predicates such as seem or appear.

\section{Conclusion}

At first sight it seems that the generative theory cannot account for developing constructions, which have not been reanalyzed into a positive parameter. Epistemic promise, for instance, does not fit into any category neatly: it shares some properties of main verbs and some of auxiliaries. Although the generative paradigm seeks to identify discrete parametric changes, it does provide tools for the analysis of less spectacular changes. Within this framework, grammaticalisation is seen as the loss of movement. As advocated by Roberts and Roussou (1999, 2005), when lexical categories become functional categories, movement is lost and a new exponent for the higher functional head, corresponding to the previous target of movement, is created. In other words, lexical categories undergo movement to a functional position in order to check relevant features. When they become functional categories, they are base-generated in the functional position. This idea can also be applied in the case of promise: as a lexical verb, it is generated in $\mathrm{V}$ and then moved to $\mathrm{v}$; as a functional verb, it is base-generated in v. On the whole, this approach refutes the major argument underlying the claim that grammaticalisation is not applicable to generative accounts of language: that it does not account for a) the gradience of word-class membership; b) layering (the availability of two structures at the same time, for instance the lexical and the epistemic/ functional promise); c) the identifiable directions of change. Upon closer scrutiny, there are no inconsistencies between the grammaticalisation theory and the generative paradigm. As the example of epistemic promise shows, the gradience of word-class membership is possible within the generative framework. So is layering: at present, there are two kinds of promise in English: the lexical one, merged in $\mathrm{V}$ and the functional one, base-generated in v. Finally, it has been claimed that grammaticalisation proceeds in identifiable directions, which is inexplicable in Chomskyan terms. This, as Roberts and Roussou $(1999,2005)$ show, is not true. The direction is identifiable since grammaticalisation changes follow a path structurally defined by the hierarchy of the functional categories. 
Maja Lubańska, Grammaticalisation and generative theory: ...

All things considered, the grammaticalisation theory and the generative theory are compatible, yet they are not supposed to match as they investigate different matters. The grammaticalisation theory is performance-based, the generative model is competence-based. They are complementary if, ontologically, they are perceived as autonomous domains of inquiry.

\section{References}

Burzio, L. (1986). Italian syntax. Dordrecht: Reidel.

Chomsky, N. (1995). The minimalist program. Cambridge, MA: MIT Press. Chomsky, N. (2000). Minimalist inquiries: The framework. In: R. Martin, D. Michaels,\& J. Uriagereka (Eds.), Step by step: Essays on minimalist syntax in honor of Howard Lasnik (pp.98-155). Cambridge, Mass.: MIT Press.

Chomsky, N. (2001). Derivation by phase. In M. Kenstowicz (Ed.) Ken Hale: A life in language (pp. 1-52). Cambridge, MA: MIT Press.

Chomsky, N. (2004). Beyond explanatory adequacy. In A. Belletti (Ed.) Structures and beyond. (pp.104-131). Oxford: Oxford UP.

Chomsky, N. (2005). Three factors in language design. Linguistic Inquiry 36(1): 1-22.

Collins, P. (2009). Modals and quasi-modals in English. Amsterdam: Rodopi.

Fischer, O. \& Rosenbach, A. (2000). Introduction. In O. Fischer, A. Rosenbach \& D. Stein (Eds.), Pathways of change. Grammaticalization in English (pp. 1-37). Amsterdam: Benjamins.

Gelderen, E. van. (2008). Where did late Merge go? Grammaticalisation as feature economy. Studia Linguistica 62(3): 287-300.

Heine, B. (2003). Grammaticalisation. In B. Joseph,\& R. Janda (Eds.), The handbook of historical linguistics (pp.575-601). Oxford: Blackwell.

Heine, B. \& Kuteva, T. (2005). Language contact and grammatical change. Cambridge: Cambridge UP.

Heine, B. \& Kuteva, T. (2006). The changing languages of Europe. Oxford: Oxford UP.

Hopper, P. \& Traugott, E. (1993). Grammaticalisation. Cambridge: Cambridge UP.

Kemenade, A van. (1999). Functional categories, morphosyntactic change, grammaticalisation. Linguistics 37-6: 997-1010. 
Krug, M. (2000). Emerging English modals. A corpus-based study of grammaticalisation. Berlin: Mouton de Gruyter.

Lightfoot, D. (1979). Principles of diachronic syntax. Cambridge: Cambridge UP.

Lightfoot, D. (1991). How to set parameters: Arguments from language change. Cambridge, MA: MIT Press.

Quirk, R., Greenbaum, S., Leech, G. \& Svartvik, J. (1985). A comprehensive grammar of the English language. London: Longman.

Roberts, I. (1985). Agreement parameters and the development of English modal auxiliaries. Natural Language and Linguistic Theory 3: 21-58.

Roberts, I. (1999). Verb movement and markedness. In M. de Graff (Ed.), Language change and language creation: Creolization, diachrony, and development (pp. 287-327). Cambridge, MA: MIT Press.

Roberts, I. \& Roussou, A. (1999). A formal approach to 'grammaticalisation'. Linguistics 37: 1011-1041.

Roberts, I. \& Roussou, A. (2005). Syntactic change. A minimalist approach to grammaticalisation. Cambridge: Cambridge UP.

Swan, M. (2002). Practical English usage. Oxford: Oxford UP.

Traugott, E. C. (1993). The conflict promises/threatens to escalate into war. In J. S. Guenter, B. A. Kaiser, \& C. C. Zoll (Eds.), Proceedings of the Nineteenth annual Meeting of the Berkeley Linguistics Society (pp. 348358). Berkeley, CA: Berkeley Linguistics Society.

Traugott, E. C. (1997). Subjectification and the development of epistemic meaning: The case of promise and threaten. In T. Swan \& O. J. Westvik (Eds.), Modality in Germanic languages. Historical and comparative perspectives (pp. 185-210). Berlin: Mouton de Gruyter.

Traugott, E. C. \& Heine, B. (Eds.). (1991). Approaches to grammaticalisation. [Typological Studies in Language 19], 2 vols. Amsterdam: Benjamins.

Verhagen, A. (1995). Subjectification, syntax, and communication. In D. Stein \& S. Wright (Eds.), Subjectivity and subjectivisation: Linguistic perspectives (pp. 103-128). Cambridge: Cambridge UP.

Verhagen, A. (2000). "The girl that promised to become something": An exploration into diachronic subjectification in Dutch. In T. F. Shannon \& J. P. Snapper (Eds.), The Berkeley conference on Dutch linguistics 1997: the Dutch language at the millennium (pp. 197-208). Lanham, MD: University Press of America.

Wurmbrand, S. (2001). Infinitives. Restructuring and clause structure. Berlin, New York: Mouton de Gruyter. 
Maja Lubańska, Grammaticalisation and generative theory: ...

\title{
Internet sources
}

The British National Corpus (Online service). Managed by Oxford University Computing

Services on behalf the BNC Consortium. URL: http://www.natcorp.ox.ac.uk Davies, M. (2008-). The Corpus of Contemporary American English (COCA): 400+ million words, 1990-present. Available online at http://www.americancorpus.org

Accepted for publication on 1 October 2010.

\author{
Маја Лубанска \\ Универзитет у Вроцлаву, Пољска
}

ГРАМАТИКАЛИЗАЦИЈА И ГЕНЕРАТИВНА ТЕОРИЈА:

СЛУЧАЈ ЕПИСТЕМИЧКОГ РROMISE

\section{Сажетак}

На теорију граматикализације и генеративну теорију се устаљено гледа као на у знатној мери инкомпатибилне у њиховим исходишним претпоставкама (уп. Ван Кеменаде 1999, Фишер и Розенбах 2000). Сходно овоме, процес граматикализације се често схвата као неприменљив у генеративном објашњењу језика. Циљ овог рада је да покаже супротно. Следећи нит размишљања дат у раду Робертса и Русуа (1999, 2005), у раду се анализира развој епистемичког promise у енглеском језику да би се показало да теорија Чомског не само да може да објасни нагле, категоријалне промене, већ и оне које су постепене и текуће.

Кључне речи: граматикализација, генеративна теорија, модалност, епистемичка модалност, семантички фактори, когнитивни фактори, прагматски фактори, минималистичка граматика, морфосинтаксичка промена, усвајање језика 
